\title{
A Short Season Canadian Soybean Cultivar Double Cropped After Winter Wheat in Uzbekistan With and Without Inoculation with Bradyrhizobium
}

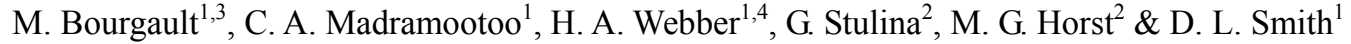 \\ ${ }^{1}$ Faculty of Agricultural and Environmental Sciences, McGill University, Ste-Anne-de-Bellevue, Canada \\ ${ }^{2}$ Central Asian Research Institute of Irrigation (SANIIRI), Tashkent, Republic of Uzbekistan \\ ${ }^{3}$ Current address: Faculty of Veterinary and Agricultural Sciences, The University of Melbourne, Creswick, \\ Australia \\ ${ }^{4}$ Current address: University of Bonn, Crop Science Group, Bonn, Germany \\ Correspondence: Donald Smith, Department of Plant Science, Macdonald campus, Ste-Anne-de-Bellevue, QC, \\ H9X 3V9, Canada. Tel: 1-514-398-7866. E-mail: donald.smith@mcgill.ca
}

Received: June 4, 2014 Accepted: July 14, 2015 Online Published: July 17, 2015

doi:10.5539/jps.v4n2p74 URL: http://dx.doi.org/10.5539/jps.v4n2p74

\begin{abstract}
Agricultural systems in Uzbekistan are dominated by the production of cotton and winter wheat as these crops are subject to state-prescribed quotas. An experiment was conducted in the Fergana valley, in Uzbekistan, Central Asia, to determine the feasibility of growing a short-season Canadian soybean (Glycine max [L.] Merr.) cultivar after the harvest of winter wheat in early July. An inoculated treatment was compared to a non-inoculated control in a randomized complete block design with four blocks. While the inoculation did not establish well in 2003, in 2004, the yield of inoculated soybean was twice that of the non-inoculated control (106\% increase). Inoculation in 2004 increased seed weights by $30 \%$, final pod number by $29 \%$, biomass dry weight at the pod-filling stage (56\%) and at harvest $(56 \%)$, as well as the harvest index by $22 \%$. Nodules were, in general, only present in the inoculated treatments, which indicated that appropriate indigenous rhizobial strains were not present in these soils, but ineffective rhizobial competitors to commercial inoculants were also absent. Soybean production could be possible in Uzbekistan without competing with state prescribed crops such as cotton and winter wheat. Based on prices from 2004, this represents an additional income of more than $300 \$ \mathrm{ha}^{-1}$. More research is needed to determine the optimal conditions for inoculation success in hot and dry climates.
\end{abstract}

Keywords: double cropping, farming systems, Glycine max, inoculation, Uzbekistan

\section{Introduction}

Agricultural policies in Uzbekistan emphasize the culture of cotton, an important component of the Uzbek economy, and to a lesser degree, winter wheat. Both are subject to state regulation through a system of quotas, and little agricultural land is left for other crops. A typical rotation starts with cotton being planted in April, and harvested from September to December. Winter wheat is planted in November to December, in between rows of cotton, and harvested late June to mid-July in the following year. The land is then kept fallow until April when cotton is planted once again. To improve land productivity and food security in the region, the introduction of food legumes as double crops after the harvest of winter wheat was previously suggested (Bourgault et al., 2013). In many systems, the intensification of agriculture with double cropping is a major tool to improve the efficiency of resource use, such as water and radiation use efficiency (Van Opstal et al., 2011; Fouli et al., 2012). In the Fergana valley, the period between July and mid-October represents over $40 \%$ of the total yearly radiation (data taken from Pereira et al., 2009; Table 2). In addition, legumes in rotation with other crops can break disease cycles, improve the fertility and structure of the soil and encourage the development of mycorrhizal associations (Subbarao et al., 1995).

Soybean (Glycine max [L.] Merr.) is now the world's most important legume crop (Giller, 2001). Its annual production totalled 276 million tonnes in 2013 on over 110 million hectares averaging producer prices of US 
\$525 tonne $e^{-1}$ in 2012 (FAOSTAT, 2015). Soybean is used both as a food crop and for its oil, and the meal resulting from oil extraction is an important protein source for livestock. International markets for soybean are well developed and easy to access, and its production has been growing including in several dry areas such as Australia, Brazil and the United States (FAOSTAT, 2015). While short-duration soybean cultivars have been developed in Canada to avoid cold temperatures, no such short-duration cultivars are available to Uzbek farmers. Local Uzbek soybean cultivars generally mature in at least 120 days, and are thus in direct competition with government-prescribed production of cotton and winter wheat. As such, we hypothesized that the soybean cultivar Costaud, which matures in 90 to 100 days under Canadian conditions, would represent a good candidate for production under the conditions of Uzbekistan.

While the benefits of inoculating soybean are well established, the ability of native rhizobial populations in the soils of Fergana valley to form functional symbioses with soybean was not known prior to our work, and the performance of both the Canadian cultivar and the inoculum had to be assessed before encouraging farmers to grow soybean. Thus, the objective of this experiment was to determine the feasibility of growing a short-season Canadian soybean cultivar after the harvest of winter wheat in early July, and to evaluate the benefits from inoculation with Bradyrhizobium japonicum under these circumstances.

\section{Materials and Methods}

\subsection{Location and Field Preparation}

The experiment was conducted in the Fergana valley, in Uzbekistan, Central Asia $\left(40^{\circ} 23^{\prime} \mathrm{N}, 71^{\circ} 45^{\prime} \mathrm{E}\right)$ from mid-July to mid-October, in the growing seasons of 2003 and 2004. During this period, the climate was hot and dry, with typical daily high temperatures of $40^{\circ} \mathrm{C}$ and daily low temperatures of $20^{\circ} \mathrm{C}$. Rain was infrequent, except in early October: from July $15^{\text {th }}$ to September $30^{\text {th }}, 2003$ and 2004, we recorded a total of 8.8 and $7.6 \mathrm{~mm}$ of rainfall, respectively, at our field sites. Climatic data (Figure 1) were collected using an on-site Vantage Pro Meteorological station (Davis Instruments Corp., Hayward, CA, USA), located approximately $200 \mathrm{~m}$ from the field site.
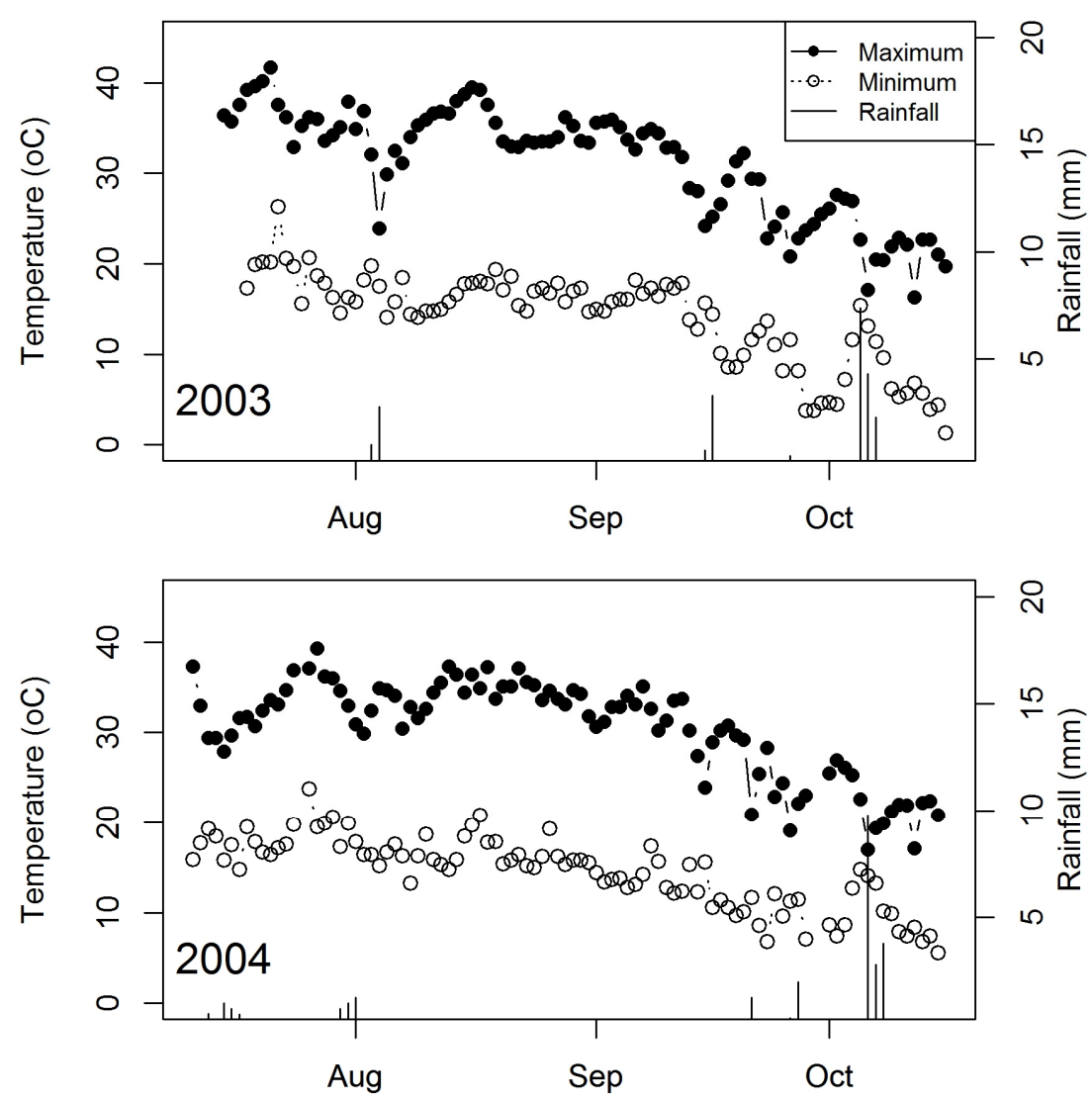

Figure 1. Climatic data for the growing seasons of 2003 and 2004 in the Fergana Valley, Uzbekistan $\left(40^{\circ} 23^{\prime} \mathrm{N}\right.$, $\left.71^{\circ} 45^{\prime} \mathrm{E}\right)$ from the beginning of July until the end of October 
Based on textural analyses, soil at the experimental sites was silt loam. The available water content was $96 \mathrm{~mm}$ in 2003 and $75 \mathrm{~mm}$ in 2004, in the top $60 \mathrm{~cm}$. The organic matter content was less than $2 \%$ and the soils had a well-developed plough pan at 30-40 cm depth.

Each field site produced winter wheat immediately prior to our experimentation. The wheat had been harvested, the straw and stubble burned, and the field ploughed and levelled, all following standard practices in the region. Neither experimental site had any history of soybean production. Sixty-centimeter-wide furrows were formed on the field site with a tractor-drawn lister.

\subsection{Irrigation Scheduling}

Irrigation scheduling was performed using a water balance and evapotranspiration estimates from climatic data as described in Allen et al. (1998) and in Webber et al. (2006). There were 5 irrigation events in both years (including an irrigation just prior to planting), which brought back soil moisture to field capacity, for a total irrigation applied of approximately 3650 and $4000 \mathrm{~m}^{3} \mathrm{ha}^{-1}$ in 2003 and 2004 respectively.

\subsection{Experimental design}

Plots consisted of 9 raised beds $5 \mathrm{~m}$ in length. Each plot was separated by a double row of mutant non-nodulating soybean plants. The plots were organized on the field site following a randomized complete block design with four blocks and two treatments. The treatments consisted of inoculated plots, and control non-inoculated plots.

\subsection{Inoculation and Planting}

The cultivar used was Costaud (Agrocentre Belcan, Ste-Marthe, QC, Canada), one of the shorter duration cultivar available in Canada at the time of the experiment. Seeds were covered with a slurry prepared from $10 \mathrm{~g}$ of commercial peat-based inoculant containing Bradhyrhizobium japonicum strain 532C (Nitragin, EMD Crop Bioscience, Milwaukee, WI, USA), and $15 \mathrm{~mL}$ of water, as directed on the package. Nitragin guarantees a minimum of 250 million viable bacterial cells per gram. Planting was done on July $22^{\text {nd }}$ in 2003 , and on July $13^{\text {th }}$ in 2004. Seeds were sown by hand, with the non-inoculated control planted first to avoid contamination. Seeds were sown at $5 \mathrm{~cm}$ depth, on both sides of the raised bed to achieve a planting density of 50 plants $\mathrm{m}^{-2}$. Weed control was done manually throughout the season.

\subsection{Data Collected}

Yield was measured by harvesting all pods in three randomly selected 2-m length sections of row in each plot, but at least $1 \mathrm{~m}$ away from the edge of the plot, and two outside rows were not utilized for data collection. Pods were threshed by hand, and seed yield was corrected for moisture content (to $0 \%$ moisture), and converted in $\mathrm{kg}$ $\mathrm{ha}^{-1}$ from plant population estimates before statistical analysis. The number of seeds per pod was evaluated on ten randomly selected pods from these areas, and seed weight was evaluated from one hundred seeds randomly selected from the harvested seeds from each plot. These were then oven-dried at $65-70{ }^{\circ} \mathrm{C}$ for $24 \mathrm{~h}$, or until completely dry, to determine seed moisture level. Plant population estimates were determined by counting the number of plants in three 2-m length sections per plot.

To determine crop height and the number of flowers and pods, six plants were labelled at the beginning of the season and measurements were made on a weekly basis on these same plants until harvest. Above-ground biomass was also evaluated three times during the season at the flowering, pod-filling and harvest stages by sampling randomly $0.5 \mathrm{~m}$ of row. Plants were dried at $70^{\circ} \mathrm{C}$ for at least $24 \mathrm{~h}$, until completely dry. The number of nodules and their dry weight were also determined in these destructive samplings. The nitrogen content and carbon to nitrogen ratio of the above-ground biomass was also determined with an elemental analyser (NC 2500 Elemental Analyzer, CE Instrument Inc., Milan, Italy). Non-nodulating soybean nitrogen contents were also looked at separately to ensure there was no spatial variability within the field.

\subsection{Statistical Analyses}

Statistical analyses were performed by analysis of variance (ANOVA) using the SAS/STAT software and GLM procedure (SAS, Cary, NC, USA). Because there were few nodules on the control plants, the analysis for the number of nodules was performed with a non-parametric approach using proc RANK prior to proc GLM.

\section{Results}

In both years, a soybean crop was grown to maturity using a short-season Canadian variety after the harvest of winter wheat in the Fergana valley, in Uzbekistan, Central Asia. Soybean yields averaged 1.0 and $1.4 \mathrm{t} \mathrm{ha}^{-1}$ in 2003 and 2004, respectively (Table 1), for inoculated soybean. Inoculation increased yields by $106 \%$ in 2004, but did not significantly increase yields in 2003. In fact, very few nodules were observed in 2003 (Table 1). 
The higher yield observed due to inoculation in 2004 is mostly explained by higher seed weights (30\% increase) and higher final pod numbers (29\% increase), as compared to the control non-inoculated soybean plants (Table 1). The number of seeds per pod, however, was unaffected by inoculation. Nodules were not generally found on plants in the non-inoculated control treatment plots (Table 2).

Table 1. Yield and yield components of soybean grown in Uzbekistan

\begin{tabular}{lllll}
\hline \multirow{2}{*}{ Parameters } & \multicolumn{2}{l}{2003} & \multicolumn{2}{l}{2004} \\
\cline { 2 - 5 } & Inoculated & Control & Inoculated & Control \\
\hline Yield (kg/ha) & $1047 \mathrm{a}$ & $968 \mathrm{a}$ & $1476 \mathrm{~A}$ & $715 \mathrm{~B}$ \\
Seeds per Pod & $\mathrm{NA}$ & $\mathrm{NA}$ & $2.45 \mathrm{~A}$ & $2.34 \mathrm{~A}$ \\
$100-$ Seed Weight $(\mathrm{g})$ & $\mathrm{NA}$ & $\mathrm{NA}$ & $16.5 \mathrm{~A}$ & $12.7 \mathrm{~B}$ \\
Final number of Pods & $41.2 \mathrm{a}$ & $39.6 \mathrm{a}$ & $33.6 \mathrm{~A}$ & $26.0 \mathrm{~B}$ \\
Above ground biomass $(\mathrm{kg} / \mathrm{ha})$ & $2573 \mathrm{a}$ & $1887 \mathrm{a}$ & $3151 \mathrm{~A}$ & $2020 \mathrm{~B}$ \\
Harvest index $(\%)$ & $41.4 \mathrm{a}$ & $57.1 \mathrm{a}$ & $47.6 \mathrm{~A}$ & $39.1 \mathrm{~B}$ \\
\hline
\end{tabular}

Values given are means of three (2003) or four blocks (2004) with the same treatment. Values associated with the same letter within the same year are not significantly different at $p<0.05$. Equipment malfunction in 2003 resulted in grains being lost before being counted.

*NA $=$ "Not available". Due to oven malfunction, data on seeds per pod and 100-sed weight were not available in 2003 .

Table 2. Average number (per $0.5 \mathrm{~m}$ row) and dry weight of nodules found in soybean grown in Uzbekistan in 2004

\begin{tabular}{lllllll}
\hline & \multicolumn{2}{l}{ Flowering } & \multicolumn{2}{l}{ Pod-Filling } & Harvest \\
\cline { 2 - 6 } Treatment & Number & Dry weight $(\mathrm{g})$ & Number & Dry weight $(\mathrm{g})$ & Number & Dry weight $(\mathrm{g})$ \\
\hline 2003 & & & & \\
Inoculated & $2.3 \mathrm{a}$ & $\mathrm{NA}^{*}$ & $8.7 \mathrm{a}$ & $\mathrm{NA}^{*}$ & $16.0 \mathrm{a}$ & NA* $^{*}$ \\
Control & $0 \mathrm{~b}$ & 0 & $0 \mathrm{~b}$ & 0 & $0 \mathrm{~b}$ & 0 \\
2004 & & & & & $13.5 \mathrm{a}$ & $0.285 \mathrm{a}^{* *}$ \\
Inoculated & $\mathrm{NA}$ & $0.185 \mathrm{a}$ & $122.5 \mathrm{a}$ & $2.338 \mathrm{a}$ & $0 \mathrm{~b}$ & $0.000 \mathrm{a}$ \\
Control & 0 & $0.000 \mathrm{~b}$ & $0.75 \mathrm{~b}$ & $0.005 \mathrm{~b}$ & 0.000
\end{tabular}

Values given are the means of four blocks with the same treatment. Values associated with the same letter within the same sampling are not significantly different at $\mathrm{p}<0.05$.

*NA = "Not available". Dry weights for the 2003 season were not available.

**The probability of significance between the inoculated and control treatments was $\mathrm{p}=0.0505$.

In 2004, the above-ground biomass dry weight began to show increasingly significant differences by the pod-filling stage $(p=0.0533$; not shown), and showed very clear differences at the harvest stage $(p=0.0098$; Table 1). The number of flowers was not affected by inoculation in either year on any of the days of observation, but the number of pods started to become greater in the inoculated treatment by mid-September (data not shown). Similarly, no differences were found in nitrogen content or nitrogen-carbon ratio at the flowering sampling. However, clear differences were detected for above-ground biomass at pod-fill and for grains at harvest (Table 3 ). The lack of differences in nitrogen content in leaves at the harvest stage suggests that most of the nitrogen from the symbiosis was translocated to grains. Our data suggest that the benefit of inoculation was greatest in the late stages of plant development. 
Table 3. Nitrogen content and Nitrogen-Carbon Ratio of Soybean Grown in Uzbekistan in 2004

\begin{tabular}{lllllllll}
\hline & \multicolumn{2}{l}{ Flowering } & \multicolumn{2}{l}{ Pod-Filling } & \multicolumn{2}{l}{ Harvest } & \multicolumn{2}{l}{ Grains } \\
\cline { 2 - 8 } Treatment & $\begin{array}{l}\mathrm{N} \text { content } \\
(\%)\end{array}$ & N-C ratio & $\begin{array}{l}\mathrm{N} \text { content } \\
(\%)\end{array}$ & $\mathrm{N}-\mathrm{C}$ ratio & $\begin{array}{l}\mathrm{N} \text { content } \\
(\%)\end{array}$ & N-C ratio & $\begin{array}{l}\mathrm{N} \text { content } \\
(\%)\end{array}$ & N-C ratio \\
\hline Inoculated & $3.98 \mathrm{a}$ & $0.0374 \mathrm{a}$ & $3.06 \mathrm{a}$ & $0.0245 \mathrm{a}$ & $2.65 \mathrm{a}$ & $0.0178 \mathrm{a}$ & $6.07 \mathrm{a}$ & $0.0491 \mathrm{a}$ \\
Control & $4.12 \mathrm{a}$ & $0.0352 \mathrm{a}$ & $2.41 \mathrm{~b}$ & $0.0187 \mathrm{~b}$ & $2.62 \mathrm{a}$ & $0.0148 \mathrm{~b}$ & $5.27 \mathrm{~b}$ & $0.0399 \mathrm{~b}$ \\
\hline
\end{tabular}

Values given are the means of four blocks with the same treatment. Values associated with the same letter within the same sampling are not significantly different at $\mathrm{p}<0.05$.

\section{Discussion}

\subsection{It is Feasible to Grow Soybean in Uzbekistan as a Double Crop}

The cultivar Costaud, although originally developed for colder climate conditions prevalent in Canada, is able to grow and yield as a double crop in the hot and dry conditions of Fergana valley, Uzbekistan, provided some irrigation is available. It averaged 1.0 and $1.4 \mathrm{t} \mathrm{ha}^{-1}$ in 2003 and 2004, respectively after the harvest of winter wheat. This provides farmers with a possible alternative crop that does not compete with the production of cotton and winter wheat, which are subject to state quotas. However, yields were low compared to the world averages of 2.3 and $2.2 \mathrm{t} \mathrm{ha}^{-1}$ for 2003 and 2004 respectively (FAO, 2015), which suggest that genetic improvement for better adapted germplasm and inoculants could lead to greater yields. While the crop was irrigated, transient water stress during the day (with temperatures as high as $40{ }^{\circ} \mathrm{C}$ ) were likely.

The production of an additional crop in the cotton-wheat rotation does require additional water. However, excessive water is often applied to furrow irrigated cotton and wheat in the region, and various strategies have been put forward to reduce irrigation amounts applied while maintaining yields (Horst et al., 2007; Pereira et al., 2009). For example, Horst et al. (2007) show that by irrigating cotton with surge-flow irrigation in alternate furrows, the irrigation water could be decreased by $44 \%\left(3891 \mathrm{~m}^{3} \mathrm{ha}^{-1}\right)$, which is about the amount of water necessary to irrigate soybean. Therefore water savings in cotton could compensate for the irrigation water necessary for soybean production. In 2004, the price of soybean was US $\$ 211 \mathrm{t}^{-1}$ (FAO, 2015), so this additional crop would increase income by approximately US $\$ 300 \mathrm{ha}^{-1}$.

\subsection{Importance of Environmental Conditions at Planting for Successful Nodulation}

In 2003, the inoculation of seeds at planting was done in the afternoon, but due to technical difficulties in getting irrigation water, the plots remained dry until the next morning. In 2004, the inoculation and planting were done early in the morning and irrigation water was applied immediately afterwards, such that all operations were completed by midday. We suspect that in 2003 the soil was too hot and dry for the survival of rhizobial cells in the commercial inoculant, leading to poor nodulation. The success of 2004 however seems to indicate that with proper care, this inoculant can perform relatively well.

Environmental factors such as high temperature and drought affect nodulation and the ability of rhizobia to colonize plants (Hungria \& Vargas, 2000). Our findings indicate that best management practices for soybean inoculation need to be developed for Uzbekistan as the benefits can be substantial. The manufacturer's instructions on the package (and quality assurance) are not taking into account environmental conditions that might be prevalent outside of Canada and the United States. In Australia, where the summer climate is similar, the current extension message to farmers is to inoculate and plant within $24 \mathrm{~h}$ (GRDC, 2013). Our experience suggests that even this might be too challenging for rhizobia survival. There is a real need to investigate genetic and agronomic solutions to this problem. Large variability in rhizobial strains has been documented in a number of semi-arid areas (Arun \& Sridhar, 2005; Hungria et al., 2006; Giongo et al., 2008) and are potential genetic resources. Research with Brazilian inoculants and native rhizobia isolated from calcareous soils (prevalent in the region) is also being performed in the region (Egamberdiyeva et al., 2004).

To some extent, it is advantageous that no native bacteria were found in the soils of the Fergana Valley, as this indicates that there are no ineffective competitors to compete with introduced rhizobia.

\subsection{Soybean Breeding Objectives for the Region Should Include Short Duration, Heat and Drought Tolerance}

While Canadian, northern U.S. and northern Chinese cultivars could be genetic resources of short duration traits, Brazilian and Australian germplasm could be used as source of heat and drought tolerance. In addition, large genetic variability in nodulation sensitivity to water deficit stress among soybean cultivars has been 
demonstrated (Serraj \& Sinclair, 1998), and low petiole ureide content has been associated with the maintenance of nitrogen fixation under water stress (Sinclair et al., 2000). This could provide a relatively simple method for screening soybean cultivars and rhizobial strain combinations for higher nitrogen fixation in drought-prone areas.

\section{Conclusion}

Soybean production is possible in Uzbekistan without competing with state prescribed crops such as cotton and winter wheat. This could provide farmers with an additional income to their current production systems. More research is needed to determine the optimal conditions for inoculation success in hot and dry climates and heat and drought tolerance should be breeding objectives in the region.

\section{Acknowledgements}

The authors thank the Canadian International Development Agency (CIDA) for funding the field component of this research. We further acknowledge the support of the Fonds Québécois de Recherche sur la Nature et les Technologies (FQRNT) during M. Bourgault's PhD studies, and of the National Science and Engineering Research Council (NSERC) during H. Webber's PhD studies. Thanks are also due to Prof. V. Dukhovny of the Scientific Information Centre of the Interstate Commission for Water Coordination (SIC ICWC) of Central Asia for hosting the Canadian researchers, as well to all laboratory and field staff of the organization for their help with soil analyses and irrigation scheduling. Finally, thanks are due to R. Baker, C. Senecal and N. Stampfli of the Brace Centre for their support in technical and managerial aspects of the project.

\section{References cited}

Allen, R. G., Pereira, L. S., Raes, D., \& Smith, M. (1998). Crop evapotranspiration: Guidelines for computing crop water requirements. Food and Agricultural Organization, Rome.

Arun, A. B., \& Sridhar, K. R. (2005). Growth tolerance of rhizobia isolated from sand dune legumes of the southwest coast of India. Engineering in Life Science, 5, 134-138. http://dx.doi.org/10.1002/elsc.200420061

Bourgault, M., Madramootoo, C. A., Webber, H. A., Stulina, G., Horst, M. G., \& Smith, D. L. (2013). Legume production and irrigation strategies in the Aral Sea basin: Yield, yield components, water relations and crop development of common bean (Phaseolus vulgaris L.) and mungbean (Vigna radiata (L.) Wilczek). Journal of Agronomy and Crop Science, 199, 241-252. http://dx.doi.org/10.1111/jac.12016

Egamberdiyeva, D., Qarshieva, D., \& Davranov, K. (2004). Growth and yield of soybean varieties inoculated with Bradyrhizobium spp in N-deficient calcareous soils. Biology and Fertility of Soils, 40, 144-146. http://dx.doi.org/10.1007/s00374-004-0755-1

Food and Agriculture Organisation of the United Nations Statistics Division. (2015). FAOSTAT Database. Retrieved from January 22, 2015, http://faostat3.fao.org/home/E

Fouli, Y., Duiker, S. W., Fritton, D. D., Hall, M. H., Watson, J. E., \& Johnson, D. H. (2012). Double cropping effects on forage yield and field water balance. Agricultural Water Management, 115, 104-117. http://dx.doi.org/10.1016/j.agwat.2012.08.014

Giller, K. (2001). Nitrogen fixation in tropical cropping systems. CABI Publishing, New York, USA. http://dx.doi.org/10.1079/9780851994178.0000

Giongo, A., Ambrosini, A., Vargas, L. K., Freire, J. R. J., Bodanese-Zanettini, M. H., \& Passaglia, L. M. P. (2008). Evaluation of genetic diversity of bradyrhizobia strains nodulating soybean [Glycine max (L.) Merrill] isolated from South Brazilian fields. Applied Soil Ecology, 38, 261-269. http://dx.doi.org/10.1016/j.apsoil.2007.10.016

Grains Research and Development Corporation (GRDC). (2013). Inoculating legumes: The Back pocket guide (p. 244). Coretext, Melbourne, VIC, Australia.

Horst, M. G., Shamulatov, S. S., Goncalves, J. M., \& Pereira, L. S. (2007). Assessing impacts of surge-flow irrigaiton on water saving and productivity of cotton. Agricutlural Water Management 87, 115-127. http://dx.doi.org/10.1016/j.agwat.2006.06.014

Hungria, M., Vargas, M.A.T., (2000). Environmental factors affecting N-2 fixation in grain legumes in the tropics, with an emphasis on Brazil. Field Crops Research, 65, 151-164. http://dx.doi.org/10.1016/S0378-4290(99)00084-2

Hungria, M., Chueire, L. M. O., Megias, M., Lamrabet, Y., Probanza, A., Guttierrez-Manero, F. J., \& Campo, R. J. (2006). Genetic diversity of indigenous tropical fast growing rhizobia isolated from soybean nodules. 
Plant and Soil, 288, 343-356. http://dx.doi.org/10.1007/s11104-006-9125-0

Pereira, L. S., Parades, P., Cholpankulov, E. D., Inchenkiva, O. P., \& Teodoro, P. R. (2009). Irrigation scheduling strategies for cotton to crop with water scarcity in the Fergana Valley, Central Asia. Agricultural Water Management, 96, 723-735. http://dx.doi.org/10.1016/j.agwat.2008.10.013

Serraj, R., \& Sinclair, T.R. (1998). Soybean cultivar variability for nodule formation and growth under drought. Plant and Soil, 202, 159-166. http://dx.doi.org/10.1023/A:1004300819535

Sinclair, T. R., Purcell, L. C., Vadez, V., Serraj, R., King, C. A., \& Nelson, R. (2000). Identification of soybean genotypes with N2 fixation tolerance to water deficits. Crop Science, 40, 1803-1809. http://dx.doi.org/10.2135/cropsci2000.4061803x

Subbarao, G. V., Johansen, C., Slinkard, A. E., Rao, R. C., Saxena, N. P., \& Chauhan, Y. S. (1995). Strategies for improving drought resistance in grain legumes. Critical Reviews in Plant Sciences, 14, 469-523. http://dx.doi.org/10.1080/713608125

Van Opstal, N. V., Caviglia, O. P., \& Melchiori, R. J. M. (2011). Water and solar radiation productivity of double-crops in a humid and temperate area. Australian Journal of Crop Science, 5, 1760-1766.

Webber, H. A., Madramootoo, C. A., Bourgault, M., Horst, M. G., Stulina, G., \& Smith, D. L. (2006). Water use efficiency of common bean and green gram grown using alternate furrow and deficit irrigation. Agricultural Water Management, 86, 259-268. http://dx.doi.org/10.1016/j.agwat.2006.05.012

\section{Copyrights}

Copyright for this article is retained by the author(s), with first publication rights granted to the journal.

This is an open-access article distributed under the terms and conditions of the Creative Commons Attribution license (http://creativecommons.org/licenses/by/3.0/). 